\title{
«БОРОТЬБА ЗА ДУШІ»: ПОЛЬСЬКО-РОСІЙСЬКЕ ПРОТИСТОЯННЯ В ОСВІТНІЙ СФЕРІ У ДРУГІЙ ПОЛОВИНІ ХІХ - НА ПОЧАТКУ ХХ СТ.
}

\author{
Н. Ю. Громакова
}

\begin{abstract}
Громакова Н. Ю. «Боротьба за душі»: польсько-російське протистояння в освітній сфері $\boldsymbol{y}$ друхій половині $\boldsymbol{X I X}$ - на початкy $\boldsymbol{X X} \mathbf{c m}$. У статті проаналізовано освітянський простір Наддніпрянщини в контексті розгортання боротьби між польським національним і російським імперським проектами упродовж другої половини XIX - початку XX ст. На думку автора, польські освітні практики в цей період виступали не лише потужним фактором опору урядовим стратегіям русифікації регіону, але й сприяли націоналізації свідомості місцевих поляків. Автор дійшов висновку, що за відсутності умов для легальної національно-політичної праці для поляків саме освітянська діяльність часто виступала єдиним доступним каналом збереження власної національно-культурної ідентичності. 3 іншого боку, в умовах генезису модерного суспільства саме сфера освіти ставала ареною найзапекліших змагань за «душі і свідомість», тому уряд Російської імперії з середини ХIX ст. здійснив рішучі кроки у напрямку реформування державної освітньої системи і встановлення контролю за цією важливою ланкою суспільного життя.
\end{abstract}

Ключові слова: освітні практики; громадська діяльність; модернізація; урядова стратегія; національно-культурна самобутність; русифікація.

Громакова Н. Ю. «Борьба за дуии»: польско-российское противостояние в образовательной сфере во второй половине $\boldsymbol{X I X}$ - начале $\boldsymbol{X X}$ в. В статье проанализировано образовательное пространство Надднепрянской Украины в контексте борьбы между польским национальным и российским имперским проектами в течение второй половины XIX - начала XX в. По мнению автора, польские образовательные практики в этот период выступали не только мощным фактором сопротивления правительственным стратегиям русификации региона, но и способствовали национализации сознания местных поляков. Автор пришел к выводу, что отсутствие условий для легальной национально-политической работы поляков трансформировало образовательную деятельность в единственный доступный канал сохранения собственной национально-культурной идентичности. С другой стороны, в условиях генезиса модерного общества именно сфера образования становилась ареной ожесточенной борьбы за «души и сознание», поэтому правительство Российской империи с середины XIX в. предприняло решительные шаги в направлении реформирования государственной образовательной системы и установления контроля над этим важным звеном общественной жизни.

Ключевые слова: образовательные практики; общественная деятельность; модернизация; правительственная стратегия; национально-культурная идентичность; русификация.

Hromakova N. Yu. "The Struggle for the Souls": the Polish-Russian Confrontation in Education in the Late $19^{\text {th }}$ - Early $20^{\text {th }}$ Centuries. The article deals with educational system of the Dnieper region as the area of struggle between Polish national and Russian imperial projects during the second half of $19^{\text {th }}$ - early $20^{\text {th }}$ century. According to the author, the Polish educational practices during this period became strong resistance's factor to the Russification strategy of the region by the government and contributed to the forming of Polish national consciousness. The author concluded that the absence of conditions for Poles to legitimate national and political work turned their educational activities only available channel to preserve their own national and cultural identity. On the other hand, the genesis of modern society had influenced on the sphere of education, which became area of fierce struggle for "soul and consciousness" because the Russian Empire's government made decisive steps towards the reforming of the state education system and establishing control over this important part of social life from the mid-nineteenth century.

Keywords: educational practices; social activities; modernization; government's strategy; national and cultural identity; the Russification.

Однією з визначальних рис модерних трансформацій на Сході Європи упродовж XIX початку XX ст. стала націоналізація суспільної свідомості. Формування національних проектів, що супроводжувалося вибудовуванням власного історико-політичного простору і національно-культурного ландшафту, відбувалося в умовах зростання громадської активності, поширення нових комунікативних практик, усвідомлення нових ціннісно-світоглядних 
орієнтирів. Специфіка Наддніпрянщини зумовлювалася тим, що ці терени перетворилися на арену безкомпромісної боротьби між польським національним і російським імперськонаціоналістичним проектами за домінування у регіоні. Саме на тлі цього протистояння відбувався генезис українського та єврейського національних проектів, учасники яких виявилися заангажованими у регіональні суспільно-політичні та культурницькі процеси ${ }^{1}$.

Важливою ланкою змагання за «душі і свідомість» місцевої людності стала освітня сфера, що в умовах модернізації і поширення нової націоналістичної ідеології набувала якісно нового суспільного значення. I якщо для російських урядовців реформування 3 середини XIX ст. державної системи освіти було однією із стратегій русифікації та подальшої інтеграції Правобережжя до імперських структур, для місцевої польської людності освітянські практики залишалися, нарівні із католицькою релігією, єдиними каналами плекання власної національно-культурної ідентичності. Метою нашого дослідження $\epsilon$ визначення домінантних стратегій розвитку освіти в регіоні упродовж другої половини XIX - на початку XX ст. крізь призму протистояння між польською спільнотою та імперськими адміністративними установами. Студіювання проблем польсько-російського протистояння в освітній галузі вимагає окреслення політико-правового поля, в якому діяли головні актори, з'ясування цілей та особливостей їхнього практичного досягнення, в кінцевому підсумку - визначення результативності цих зусиль.

Аналіз наукового дискурсу дозволяе стверджувати, що проблеми боротьби між польським та російськими проектами у Правобережній Україні, й зокрема у сфері освіти, викликали чималий інтерес науковців. Становлення імперської системи освіти і спроби збереження польських освітніх осередків в регіоні стали предметом студіювання Д. Бовуа, О. Ніколаєнко, О. Буравського, Н. Сейко, О. Кошолапа, А. Боднар та ін. ${ }^{2}$. Разом $з$ тим, на окремі аспекти просвітництва як складової польського суспільно-культурного розвитку у контексті національної політики царизму звертають увагу Н. Щербак, Ю. Поліщук, М. Коженьовський та ін. ${ }^{3}$.

Розвідка російської дослідниці О. Бахтуріної про основні підходи сучасної російської історіографії до дослідження імперської політики у національному питанні фокусує увагу на теоретико-методологічних принципах вивчення урядових стратегій, зокрема в освітній сфері, дозволяє більш чітко з'ясувати чинники їх трансформації, мотивацію і цілі представників влади в процесі їх реалізації․ Російські дослідники О. Міллер та Л. Горизонтов проаналізували адміністративні заходи у сфері освіти крізь призму стратегій інтеграції регіону і розв'язання «польського питання» на загальнодержавному рівні'.

Слід зазначити, що попри наявність достатнього комплексу наукових публікацій, присвячених проблемам освітянської діяльності в регіоні упродовж другої половини XIX - на початку XX ст., на нашу думку, недостатньо уваги приділено з'ясуванню ролі освіти у домінантних стратегіях реалізації польського національного та російського імперського проектів на цих теренах.

Вибудовування нового імперського простору поставило на порядок денний нові завдання. Риторика настанов Миколи I Київському Військовому, Подільському і Волинському Генерал-губернатору Д. Г. Бібікову свідчить про сприйняття владою Правобережної України як невід'ємної складової імперського організму, відповідно головним завданням визначається: «здійснити перетворення зазначених губерній, нерозривним і міцним поєднанням їх із спільною родиною Великоросійських областей, якими належить [їм - H.Г.] бути і за своїм походженням, і за більшістю населення, споконвіку православного і російського» ${ }^{6}$.

Асиміляторські зусилля влади спрямовувалися на русифікацію освітніх й адміністративних установ і в кінцевому підсумку - остаточну інтеграцію регіону. Русифікація визнавалася потужним механізмом націоналізації свідомості місцевого населення на основі формули «православ'я, самодержавство, народність» і створення противаги польському етнокультурному домінуванню. 3 іншого боку, О. Міллер дійшов висновку, що окремі представники істеблішменту, зокрема П. О. Валуєв, усвідомлювали проблематичність сприйняття місцевого селянства як «русского» ${ }^{7}$

Отже, інтеграція регіону передбачала крім політико-правової й адміністративної русифікації впровадження нових принципів просвітницької діяльності з метою виховання лояльних підданих імперії, а також націоналізації свідомості місцевого українського на- 
селення на засадах «іконної русскості». Правовим підгрунтям урядової політики у сфері освіти стала розробка законодавчих норм і приписів, що спрямовували діяльність освітніх осередків на виконання цих завдань. Російський дослідник Е. Днєпров вважає визначальною рисою дореволюційного російського законодавства у сфері освіти його похідний характер від освітньої політики держави: «Тобто не право визначало закон, а політична воля, що формувала і саме право на свій розсуд, виходячи з політичної та соціально-економічної кон'юнктури» ${ }^{8}$.

Інтегративні зусилля адміністрації щодо регіону неодмінно наражалися на «польське питання», розв'язання якого вимагало перетворення поляків на лояльних підданих правлячої династії. Як слушно зауважив Л. Горизонтов, саме на досягненні цієї мети було сфокусоване урядове бачення російсько-польського співіснування і, відповідно, набір стратегій - «від серйозних поступок на користь забезпечення політичної лояльності поляків до не менш серйозних намірів асимілювати мільйони людей»9.

Після придушення польського Січневого повстання 1863-1864 pp. зусилля царської адміністрації були спрямовані на створення в Правобережній Україні привілейованого російського середовища як противаги абсолютному домінуванню польської шляхти ${ }^{10}$. Втім, ця стратегія була приречена через низький освітньо-культурний потенціал й обмежені фінансові можливості російського елементу, а головне - внаслідок відмінностей соціальнокультурного і ментального характеру між польською шляхтою і російським дворянством. Відсутність традицій активної участі у громадському житті і суспільних процесах, самодержавний характер російської політичної системи, фундаментом якої виступали сервілізм і абсолютна лояльність династії, - усі ці чинники унеможливлювали ефективну конкуренцію російського дворянства 3 польським домінуванням в регіоні. Почуття корпоративної солідарності, виплекане багатьма поколіннями шляхетської верстви, що сприймалося як символ власної політико-правової легітимації і елітарності, залишалося потужним чинником збереження польської ідентичності упродовж всього періоду російського панування, про що неодноразово зауважували місцеві адміністратори ${ }^{11}$.

Відповіддю польської громади Правобережжя на зусилля влади щодо руйнації іiї домінування в регіоні стало формування так званого «земельного патріотизму» як засадничого ціннісно-світоглядного принципу життя місцевих поляків-землевласників. Сутність «земельного патріотизму» зводилася до прагнення зберегти свій соціально-економічний вплив у регіоні, загальмувати процес зменшення польської земельної власності і в такий спосіб протистояти зусиллям влади, спрямованим на деполонізацію краю.

Про підсумки асиміляторських зусиль урядових структур і місцевої адміністрації упродовж другої половини XIX ст. свідчить доповідна записка Миколі II, датована жовтнем 1896 р. Автор підкреслює, що традиційна політика російського уряду в регіоні спрямована на деполонізацію краю шляхом «звеличення... православ'я та російських елементів». Ці зусилля постійно наражаються на опір з боку польської громади, яка вдається до різних форм спротиву - від пасивних до пошуку засобів обійти обмежувальне законодавство «шляхом юридичної казуїстики», вважаючи себе справжніми господарями краю ${ }^{12}$.

Боротьба 3 «польською інтригою» стала важливим чинником суспільних трансформацій на всьому імперському просторі у пореформений період ${ }^{13}$. Проблематичність політичної асиміляції поляків на теренах колишньої Речі Посполитої зумовила пошук нових стратегій деполонізації краю, при цьому освітня галузь визнавалася важливою ланкою їх реалізації. Французький дослідник Д. Бовуа дійшов висновку, що головними акторами тут виступали місцеві генерал-губернатори і губернатори, які послідовно реалізовували русифікаторський курс. 1 травня 1863 р. генерал-губернатором Південно-Західного краю було накладено заборону на навчання селянських дітей при католицьких приходських церквах, згодом заборонено поширення польськомовних видань, що могли містити інформацію про історію та географію колишньої Речі Посполитої ${ }^{14} .3$ іншого боку, місцеві адміністратори взяли активну участь у розбудові мережі російських навчальних закладів, зокрема через заохочення місцевих російськомовних мешканців до відкриття приватних закладів тощо.

У 1864 р. було затверджено «Положення про початкові училища», яким вводилася єдина система початкової освіти. Навчання мало проводитися російською мовою. Загальне керівництво і контроль за навчальним процесом покладалися на училищні ради, що 
складалися з чиновників і духовенства. Нагляд за релігійно-моральним вихованням учнів, благонадійністю вчителів здійснювали місцеві священики. Усі школи підпорядковувалися Міністерству народної освіти або Синоду, а в навчальному процесі керувалися підготовленими цими відомствами програмами ${ }^{15}$.

Згідно $з$ циркулярами Міністерства народної освіти, існуючі в західних губерніях імперії польські школи підлягали закриттю. Як наслідок - на Правобережжі України були ліквідовані всі католицькі парафіяльні школи. Учням-полякам заборонялося розмовляти польською мовою у школах.

Державне законодавство жорстко регламентувало освітню справу, істотно звужуючи можливості задоволення національно-культурних запитів поляків Київської, Подільської і Волинської губерній. Не обмежуючись нижчою та середньою ланками освіти влада вдалася і до обмежень доступу поляків до вищих навчальних закладів у західних губерніях та столицях. Було запроваджено numerous clauses (тобто кількісні обмеження, відсоткову норму) для студентів польського походження. Так, 22 квітня 1866 р. Алєксандр II затвердив пропозицію щодо обмеження кількості поляків до 1/5 від загальної кількості студентів Київського університету Св. Володимира ${ }^{16}$. Ці обмеження значно звужували можливості для польської молоді щодо здобуття вищої освіти. 3 іншого боку, влада ускладнила виізд вихідців з Київського генерал-губернаторства на навчання до Королівства Польського та інших польських земель, намагаючись запобігти поширенню «польської інтриги», під якою розумілися будь-які прояви національної ідентичності поляків.

Політико-правові і соціокультурні обмеження, що запроваджувалися стосовно польських підданих імперії, змушували останніх до пошуку нових форм збереження власної національної ідентичності і, відповідно, зумовлювали новий зміст громадської активності. Зміщення акцентів у польському середовищі на площину «органічної» суспільно-корисної діяльності спричинили фокусування уваги на просвітницькій та господарській діяльності, вихованні етнічних поляків у національному дусі. Активізація суспільної та економічної діяльності розглядалися як вагомий чинник модернізації суспільства, що в перспективі мало стати передумовою відновлення польської державності ${ }^{17}$.

На нашу думку, зусилля польської громади щодо плекання власної національно-культурної ідентичності стали підгрунтям для формування таємної мережі польських навчальних закладів за умов повної відсутності легальних можливостей. Російському царизму не вдалося повністю викорінити багаторічні традиції польського шкільництва. На противагу державним російським школам у краї почали виникати неофіційні (таємні) польські школи та приватні пансіони в Луцьку, Старокостянтинові, Кам'янці-Подільському та в інших населених пунктах Правобережної України, що, як правило, утримувалися на кошти польської знаті, ксьондзів. У них навчалися діти польських поміщиків, шляхти, заможних міщан і навіть селян. У 1892 р. побачив світ указ про покарання осіб за причетність до відкриття та функціонування таємних шкіл у західних губерніях імперії18.

Посилення русифікації і прагнення зберегти власну національно-культурну самобутність сприяло переведенню освітньої діяльності поляків з публічної сфери у приватну. Саме родина в цей час перетворюється на головний осередок навчання польської мови і літератури, історії, географії тощо. Водночас у родині відбувається перше знайомство дітей 3 патріотичними ідеями, формується національна самосвідомість. Отже, польське родинне середовище заповнює прогалину в задоволенні національно-культурних потреб, що розцінюється владою як «польська інтрига» і небезпека для державного ладу.

Революційні події 1905-1907рр. спричинили певну лібералізацію освітньої політики царизму. Під тиском обставин влада змушена була визнати національно-культурні домагання поляків і піти на поступки шляхом надання дозволу на відкриття приватних навчальних закладів. Джерела засвідчують надзвичайну активність поляків щодо розбудови мережі національних освітніх осередків. У № 83 газети «Dziennik Kijowski» за 1907 p. вміщено інформацію про виступ доктора Мар'яна Стемповського, редактора «Przewodnika oświatowego», присвячений розвитку позашкільної освіти. Зокрема наголошується, що просвітництво $є$ важливою ланкою суспільної діяльності, і кожен свідомий мешканець краю повинен взяти участь у цій роботі задля формування «підвалин міцної суспільної будівлі», що, відповідаючи сучасним вимогам, повинна грунтуватися на принципах «широкого демократизму». Доповідач підкреслив нерозривний зв'язок між просвітницькою 
діяльністю поляків Наддніпрянщини та в етнічних польських землях, взявши за приклад роботу просвітницького товариства «Macierz Szkolna», що діяла в австрійській Сілезії. Він закликав місцевих поляків підтримати фінансово цю діяльність, розглядаючи їі як крок до відродження Польщі ${ }^{19}$.

Про загальнонаціональне значення освітянської діяльності у Наддніпрянщині свідчить і телеграма, надіслана до товариства «Полонія» з Кракова 15 березня 1907 р., в якій висловлюється підтримка польським студентам Київського університету, що домагалися відкриття кафедр польської мови, літератури та історії. «...Додаємо наш голос як свідчення живого почуття зв'язку і солідарності польської молоді з прагненням народу до здобуття прав, необхідних для його розвитку», йшлося у телеграмі, підписаній представниками польських громадських осередків Кракова, серед них - члени товариств «Огниво», «Союз», «Академічна читальня ім. Міцкевича», «Академічне Коло Національної Асоціації Допомоги» та ін. ${ }^{20}$.

Польська громада Наддніпрянщини із жвавим інтересом слідкувала за думською діяльністю своїх депутатів, зокрема й у питаннях формування національної системи освіти, які набули політичної конотації. «Dziennik Kijowski» інформував своїх читачів про боротьбу, що розгорнулася в Державній Думі навколо поданого членами Польського Кола проекту розвитку шкільної освіти у Королівстві Польському. На думку автора кореспонденції, шкільне питання настільки загострилося у Королівстві і $€$ настільки важливим для суспільного розвитку, що вимагає негайного розв'язання. Польські депутати Думи заявили про свій намір голосувати проти державного бюджету, якщо уряд зволікатиме 3 проведенням шкільної реформи ${ }^{21}$.

Риторика газетних публікацій свідчить про усвідомлення більшістю поляків загальнонаціонального значення освітянської діяльності. Розбудова польських освітніх осередків, їхнє фінансування за рахунок приватних пожертвувань, боротьба за можливість вивчати польську мову, літературу, історію мислилися наприкінці XIX - на початку XX ст. як запорука формування культурно-національної ідентичності і громадянський обов'язок кожного свідомого поляка, а в перспективі - важливий крок у напрямку до здобуття польської державності.

В роки реакції, що настали із поразкою революції 1905-1907 рр., царська влада знову відновила наступ на національно-культурні права поляків Південно-Західних губерній, намагаючись утвердити свій контроль в освітній царині. У звіті цивільного Волинського губернатора за 1911 р. наголошується: «...школа повинна бути обов'язково урядовою... і національною [тобто зрусифікованою - Н.Г.]... школа повинна давати не лише завершену освіту, але неодмінно практичні життєві знання, що сприяють успішній боротьбі 3 навколишніми інородцями, які... довіку будуть вороже налаштовані російській державності й народності....»22. І далі автор висловлюється щодо громадської діяльності в освітянській царині: «...У господарських справах школи представникам самоврядування повинно відводитися почесне місце, але у керівництво безпосередньо навчанням... втручання повинно бути усунене» ${ }^{23}$.

Реалізація цієї стратегії на місцях означала повернення до традиційних карально-репресивних засобів боротьби з польським просвітництвом. У відповідь на це поляки вдалися до створення мережі таємних польських шкіл, переважно у сільській місцевості, подалі від пильного контролю з боку царської адміністрації 24.3 донесення начальника Київського Охоронного відділення начальнику Київського Губернського Жандармського управління за 1908 р. дізнаємося, що «у маєтку графа Шембека у м. Бородянка (на р. Здвиж) у с. Роско ведеться пропаганда в дусі польської партії. Відкриті школи, де викладання здійснюється польською мовою і провадяться ідеї ворожнечі до росіян за участю у цій справі ксьондза». Подібна пропаганда ведеться й в околицях станції Сарни, до того ж там «заборонено поширювати російські газети, особливо «Києвлянин» ${ }^{* 25}$.

Будь-які спроби поляків легальним шляхом здобути право на вивчення польської мови наражалися на рішучий опір місцевих царських урядовців. Про це зокрема свідчить клопотання членів ковельської міської думи у 1908 р. про надання дозволу на викладання

\footnotetext{
* Російськомовна газета спочатку помірно-ліберального, а потім консервативно-монархічного спрямування, що видавалася в Києві у 1864-1919 рр.
} 
рідної мови у місцевій гімназії учням польського походження. Клопотання було відхилено спочатку Попечителем Київського учбового округу, згодом повторне звернення до Волинського губернатора також не було задоволене. Відмову обгрунтовано тим, що польська громада Ковельського повіту й м. Ковеля у кількісному відношенні «не може бути визнана не тільки переважаючою над іншими мешканцями, але й більш-менш значною». Додатковим приводом до відмови стало те, що ініціатором клопотання виступив міський голова Шумовський, поляк за походженням, якого влада підозрювала у «тяжінні до полонізму» ${ }^{26}$.

Отже, можемо зробити наступні висновки. По-перше, домінантною стратегією розвитку освіти у губерніях Правобережної України упродовж другої половини XIX - на початку $\mathrm{XX}$ ст. стало посилення русифікації, агентами якої виступали імперські адміністративні установи. Саме на них покладалася відповідальність за реалізацію цієї стратегії шляхом встановлення контролю за функціонуванням системи освітніх осередків і змістовним наповненням навчальних програм, а також обмеження громадських ініціатив в цій сфері інвестиціями у фінансово-господарську діяльність тощо.

По-друге, упродовж зазначеного періоду було розроблено цілий комплекс нормативно-правових актів, що надали русифікації характеру цілеспрямованої урядової політики у галузі освіти і за допомогою яких регламентувалася діяльність всіх ланок навчально-виховного процесу. Головною метою визнавалося перетворення Південно-Західного краю на невід’ємну складову Російського державного простору, ментальне мапування якого підважувало імперське націєтворення модерної доби. Ці терени перетворилися на арену безкомпромісного змагання між польським і російським проектами, які апелювали до історичного минулого й намагалися довести культурну спорідненість 3 місцевим населенням у процесі обгрунтування власних претензій на Правобережжя.

Студіювання проблем польсько-російського протистояння в освітній галузі показало, що специфіка реалізації зазначених стратегій полягала у забороні будь-яких проявів національної самосвідомості і громадських ініціатив, пов'язаних із прагненням поляків до плекання власної етнокультурної самобутності. У свою чергу, така політика неодмінно викликала спротив, формами якого стали виїзд польської молоді на навчання до Королівства Польського і Галичини, а також відкриття таємних шкіл. 3 іншого боку, певна лібералізація національної політики в умовах російської революції 1905-1907 рр. і формування польського представництва у Державній Думі дозволили перевести питання шкільництва у політичну площину і домагатися проведення відповідної реформи.

Традиції польського шкільництва перетворилися на один з символів національної боротьби, який підтримували навіть найконсервативніші соціальні групи - землевласники і католицька церква. Сприйняття позитивістських ідей «органічної праці» сприяло усвідомленню суспільної значущості підтримки національної освіти. I хоча влада докладала чимало зусиль для остаточної русифікації регіону, втім польській громаді вдалося в цілому зберегти власну національно-культурну самобутність, перш за все через приватне родинне навчання і виховання. Важливим каналом підтримки польських ініціатив в освітній галузі стало налагодження контактів з різними громадськими осередками Королівства Польського і Галичини, що виступали прикладом приватних ініціатив у реформуванні цієї значущої суспільної ділянки.

${ }^{1}$ Гаухман М. В. Російська національна політика на Правобережній Україні (1905-1914): чотири національні проекти в одному політичному просторі / М. В. Гаухман // Дриновський збірник / Дриновски сборник. T. IV. Харків-Софія: Академічне видавництво «Проф. Марин Дринов», 2011. C. 141-150. URL: http://periodicals.karazin.ua/drinov/article/view/778 (дата звернення: 08.05.17).

${ }^{2}$ Бовуа Д. Гордиев узел Российской империи: Власть, шляхта и народ на Правобережной Украине (1793-1914). М.: Новое литературное обозрение, 2011. 1008 с. с ил.; Боднар А. М. Зміни освітнього рівня та світоглядних цінностей подолян наприкінці XVIII - в середині XIX ст. // Гілея: науковий вісник. 2013. Вип. 71 (№ 4). С. 58-61; Буравський О. А. Поляки Волині у другій половині XIX - на початку XX ст. Житомир: Вид-во ЖДУ, 2004. 168 с., іл.; Горохов С. В. Польсько-російське протистояння в освітній сфері на прикладі Київської губернії на поч. XIX століття. URL: http://nbuv.gov. ua/UJRN/Npifznu_2014_38_12 (дата звернення: 08.05.17); Громакова Н. Ю. Громадська діяльність поляків Правобережжя у сфері освіти упродовж XIX ст. // Вісник аграрної історії. Науковий журнал. 2015. Вип. 13-14. С. 188-196; Кочолап О. Ф. Політичні передумови розвитку освіти на Поділлі в 
пореформений період. URL: http://nbuv.gov.ua/UJRN/Znpkhist_2012_5_22 (дата звернення: 08.05.17); Ніколаєнко $O . О$. Жіноча освіта в середовищі польського населення Південно-Західних губерній Російської імперії в 60-х роках XIX - на початку XX ст. URL: http://nbuv.gov.ua/UJRN/Ians_2008_2_21 (дата звернення: 08.05.17); $\ddot{I i ̈ ~ ж . ~ П о л ь с ь к а ~ п а н с і о н н а ~ ж і н о ч а ~ о с в і т а ~ н а ~ П р а в о б е р е ж ж і ~ н а п р и к і н ц і ~}$ XIX ст.// «Історичні регіони України: минуле та сучасність»: матеріали Всеукраїнської наукової конференції. Харків, 2013. С. 80-83; Сейко Н. А. Доброчинність поляків у сфері освіти України (XIX - поч. ХХ ст.). Київський учбовий округ. Житомир: ЖДУ, 2006. 318 с.

${ }^{3}$ Громакова Н. Ю. Освітні практики як чинник формування польського національного проекту. URL: http://intermarum.zu.edu.ua/article/view/90328 (дата звернення: 08.05.17); Коженьовський M. За Золотими ворітьми. Суспільно-культурна діяльність поляків у Києві в 1905-1920 роках. К.: Дух і Літера, 2015. 664 с.; Поліщук Ю. М. Національні меншини Правобережжя України у контексті етнічної політики Російської імперії (кінець XVIII - початок XX ст.). К.: ІПіЕНД ім. І. Ф. Кураса НАН України, 2012. 432 с.: Щербак Н. О. Національне питання в політиці царизму у Правобережній Україні (кінець XVIII - початок XX ст.). К.: ПЦ «Ризографіка», 2005. 615 с.; Штан Г. В. Польський національний рух у Російській імперії (1905-1914 рр.): автореф. ...дис. канд. іст. наук. Харків, 2009. 28 с.

${ }^{4}$ Бахтурина A. «Национальный вопрос» в Российской империи в постсоветской историографии. URL: http://polit.ru/article/2008/06/20/bahturina/ (дата звернення: 08.12.17).

${ }_{5}^{5}$ Горизонтов Л. Е. Парадоксы имперской политики: Поляки в России и русские в Польше (XIX - начало XX в.). М.: Индрик, 1999. 272 с.; Миллер А. Украинский вопрос в Российской империи. К.: Laurus, 2013. $416 \mathrm{c}$.

${ }^{6}$ Центральний державний історичний архів у м. Києві (далі - ЦДІАК України), Ф. КМФ № 12.

Оп. 1. Спр. 22. Арк. 5зв.

${ }^{7}$ Миллер А. Украинский вопрос в Российской империи. С. 161.

${ }^{8}$ Днепров Э. Д. Законодательная деятельность в сфере образования в дореволюционной России // Вопросы образования. 2015. № 2. С. 241-278. URL: https://vo.hse.ru/2015--2/152236630.html (дата звернення: 04.05.17).

${ }^{9}$ Горизонтов Л. Е. Парадоксы имперской политики: Поляки в России и русские в Польше (XIX - начало XX в.). С. 8.

${ }^{10}$ Миллер А. Украинский вопрос в Российской империи. С. 158-159.

${ }^{11}$ ЦДІАК України. Ф. 442. Оп. 637. Спр. 545. Арк. 51 зв.; Ф. 442. Оп. 642. Спр. 497. Арк. 13-13зв.

${ }^{12}$ Там само. Ф. 442. Оп. 846. Спр. 463. Арк. 5-5зв.

${ }^{13}$ Горизонтов Л. Е. Парадоксы имперской политики: Поляки в России и русские в Польше (XIX - начало XX в.). С. 46, 216.

${ }^{14}$ Бовуа Д. Гордиев узел Российской империи... С. 811-812.

${ }^{15}$ Высочайше утвержденное Положение о начальных народных училищах (14 июля 1864 г.) / Полное собрание законов Российской империи. Собрание II (1825-1881). T. 39 (1864). URL: http:// www.nlr.ru/e-res/law r/search.php (дата звернення: 04.05.17).

${ }^{16}$ Бовуа Д. Гордиев узел Российской империи... С. 814.

${ }^{17}$ Вандич П. Ціна свободи. Історія Центрально-Східної Европи від Середньовіччя до сьогодення. К.: Критика, 2004. 462 [2] с. С. 230.

${ }_{18}^{18}$ Буравський О. А. Поляки Волині у другій половині ХІХ...С. 104.

${ }^{19}$ Dziennik Kijowski. 1907. 10 (23) квітня.

${ }^{20}$ Там само. 1907. 4 (17) квітня.

${ }^{21}$ Там само. 1907. 3(16) червня.

${ }^{22}$ ЦДІАК України. Ф. 442. Оп. 642. Спр. 497. Арк. Ззв.

${ }^{23}$ Там само. Арк. 4зв.

${ }^{24}$ Там само. Арк. 123в.

${ }^{25}$ ЦДІАК України. Ф. 274. Оп. 1. Спр. 2577. Арк. 40.

${ }^{26}$ Там само. Ф. 442. Оп. 858. Спр. 114. Арк. 1-1зв. 